\author{
IZABELLA GIL \\ ORCID: 0000-0001-9214-5503 \\ Uniwersytet Wrocławski \\ Instytut Prawa Cywilnego \\ Zakład Postępowania Cywilnego
}

\title{
ZAWIESZENIE I PODJECIE DZIAŁALNOŚCI GOSPODARCZEJ PRZEZ SPÓŁKĘ Z O.O.
}

\begin{abstract}
Abstrakt: W opracowaniu opisano dotychczasowe nieprawidłowe regulacje prawne i ich skutki w zakresie zawieszenia prowadzenia działalności gospodarczej przez spółkę z o.o. Ponadto przedstawiono zagadnienie dopuszczalności stosowania przez sądy postępowania przymuszającego do złożenia sprawozdania finansowego. Wskazano, jakiego rodzaju sankcje mogą być stosowane za niedopełnienie obowiązków złożenia rocznego sprawozdania finansowego przez spółki z o.o. Na zakończenie omówiono wprowadzone zmiany ujednolicające regulacje związane z zawieszeniem prowadzenia działalności gospodarczej.
\end{abstract}

Słowa kluczowe: działalność gospodarcza, spółka z o.o., zawieszenie i podjęcie działalności gospodarczej

\section{DOTYCHCZASOWE NIEPRAWIDŁOWE REGULACJE PRAWNE I ICH SKUTKI W ZAKRESIE ZAWIESZENIA PROWADZENIA DZIAŁALNOŚCI GOSPODARCZEJ PRZEZ SPÓŁKĘ Z O.O.}

Swoboda prowadzenia działalności gospodarczej przejawia się w możliwości nie tylko rozpoczynania prowadzenia działalności gospodarczej, ale także czasowego jej zaprzestania lub zakończenia w dowolnym momencie. Dotychczasowe regulacje prawne zawarte $\mathrm{w}$ ustawie o swobodzie prowadzenia działalności gospodarczej ${ }^{1}$ i ustawie o rachunkowości ${ }^{2}$ nie były skorelowane z ustawą o Krajo-

1 Ustawa z dnia 2 lipca 2004 roku o swobodzie działalności gospodarczej (tekst jedn. Dz.U. z 2017 r. poz. 2168 ze zm.), która z dniem 30 kwietnia 2018 roku została uchylona na mocy przepisu art. 192 ustawy z dnia 6 marca 2018 roku Przepisy wprowadzające ustawę, prawo przedsiębiorców oraz inne ustawy dotyczące działalności gospodarczej (Dz.U. z 2018 r. poz. 650).

2 Ustawa z dnia 29 września 1994 roku o rachunkowości (tekst jedn. z 2019 r. poz. 351 ze zm.). 
wym Rejestrze Sądowym ${ }^{3}$. Powodowało to, że w praktyce obrotu gospodarczego spółki, a w zasadzie prezesi spółek z o.o., wzywani byli (przez referendarzy sądowych) do złożenia sprawozdania rachunkowego na podstawie przepisu art. 22 k.r.s., mimo złożenia przez spółkę wniosku o zawieszenie prowadzenia działalności gospodarczej. Wynikało to zapewne z pomijania regulacji prawnych zawartych W ustawie o rachunkowości. W wypadku złożenia przez organy uprawnione do reprezentacji spółki z o.o. (na podstawie art. 22a ustawy k.r.s. ${ }^{4}$ ) wniosku o zawieszenie działalności (co powinno znaleźć wyraz w aktach rejestrowych spółki), na spółce nie spoczywa już obowiązek składania sprawozdania rachunkowego. W związku z tym, że wpis do KRS informacji o zawieszeniu wykonywania działalności gospodarczej polega na zamieszczeniu (w dziale 6, rubryka 8 rejestru przedsiębiorców) daty rozpoczęcia zawieszenia wykonywania działalności gospodarczej, to okoliczność ta jest jawna dla wszystkich podmiotów.

Stosownie do obowiązującego dotychczas przepisu art. 14a ustawy o swobodzie działalności gospodarczej przedsiębiorca niezatrudniający pracowników mógł zawiesić wykonywanie działalności gospodarczej na okres od 1 do 24 miesięcy. Przepis ten dotyczył także spółek z ograniczoną odpowiedzialnością. Okres zawieszenia działalności spółki z o.o. rozpoczynał się od dnia wskazanego we wniosku o wpis informacji o zawieszeniu wykonywania działalności gospodarczej, jednakże nie wcześniej niż od dnia złożenia wniosku. W wypadku zawieszenia wykonywania działalności i faktycznie niewykonywania działalności również nie było obowiązku składania sprawozdania rachunkowego. W związku z tym nie można pomijać, że zawieszenie wykonywania działalności gospodarczej pozwalało przedsiębiorcom (w tym spółkom z o.o.) — bez konieczności ostatecznego wyrejestrowania firmy - na przerwę w opłacaniu składek na ubezpieczenia społeczne i zdrowotne, a także w składaniu deklaracji i płacenia zobowiązań podatkowych. Spółka z o.o. w okresie zawieszenia nie miała także prawnego obowiązku opłacania zaliczek na podatek dochodowy od osób prawnych. W tych latach podatkowych, w których spółka od początku do końca każdego roku pozostawała w stanie faktycznego zawieszenia działalności gospodarczej i nie wystąpiły zdarzenia gospodarcze mające wpływ na powstanie obowiązku podatkowego (lub jego zmianę w stosunku do lat ubiegłych), spółka w okresie zawieszenia działalności nie miała także obowiązku prowadzenia ksiąg rachunkowych, a ponadto nie miała obowiązku składania do urzędu skarbowego zeznania podatkowego ani sprawozdania finansowego.

Stosownie do przepisu art. 12 ust. 3b ustawy z dnia 29 września 1994 roku o rachunkowości ${ }^{5}$ można było nie zamykać ksiąg rachunkowych za rok obrotowy, w którym działalność jednostki przez cały czas pozostawała zawieszona, chyba że

${ }^{3}$ Ustawa z dnia 20 sierpnia 1997 roku o Krajowym Rejestrze Sądowym (tekst jedn. Dz.U. z 2019 r. poz. 1500), dalej: k.r.s.

${ }^{4} \mathrm{Na}$ formularzu KRS-Z62 wniosku o zmianę danych podmiotu w rejestrze przedsiębiorców, zawieszenie wykonywania działalności gospodarczej.

5 Tekst jedn. Dz.U. z 2017 r. poz. 2342. 
jednostka dokonywała odpisów amortyzacyjnych lub umorzeniowych bądź nastąpiły inne zdarzenia wywołujące skutki o charakterze majątkowym lub finansowym. Przedmiotowy przepis stanowił zatem lex specialis w stosunku do przepisu art. 69 ustawy o rachunkowości. Oznacza to, że w sytuacji, gdy działalność spółki z o.o. pozostawała zawieszona przez cały rok obrotowy, nie należało zamykać ksiąg rachunkowych i sporządzać sprawozdania finansowego (za lata objęte zawieszeniem działalności). Spółka za ten okres rozliczeniowy nie mogła mieć żadnych operacji gospodarczych, na przykład odpisów amortyzacyjnych lub umorzeniowych, opłat za energię elektryczną, czynsz, gaz lub za prowadzenie rachunku bankowego, oraz nie mogła osiągać przychodów, przykładowo w postaci odsetek od środków zgromadzonych na rachunku bankowym. Przepis ust. $3 b$ ustawy o rachunkowości nie miał zastosowania jedynie do emitentów papierów wartościowych, którzy zamierzali ubiegać się o dopuszczenie lub ubiegających się o dopuszczenie do obrotu na rynku regulowanym w państwie należącym do Europejskiego Obszaru Gospodarczego oraz emitentów papierów wartościowych dopuszczonych do obrotu na tym rynku.

Spółka prawa handlowego będąca w zawieszeniu mogła, prowadząc pełną rachunkowość, nie przeprowadzać inwentaryzacji i nie zamykać ksiąg rachunkowych. $\mathrm{Z}$ tego przywileju można było skorzystać, gdy podczas danego roku obrotowego, w którym jednostka zawiesiła działalność, nie wystąpiło żadne zdarzenie gospodarcze. Podatnicy opłacający podatek dochodowy na zasadach ogólnych w okresie, kiedy nastąpiło zawieszenie spółki prawa handlowego, byli zwolnieni z obowiązku wpłacania zaliczek na podatek dochodowy, bez względu na formę płacenia zaliczek do urzędu skarbowego, to jest miesięcznie, kwartalnie, w uproszczonej formie - 1/12 podatku należnego wynikającego z zeznania złożonego w roku ubiegłym, a także składania sprawozdania finansowego i bilansu za rok kalendarzowy, w którym zawieszona była działalność gospodarcza. W wypadku zawieszenia prowadzenia działalności gospodarczej na spółce nie spoczywał obowiązek składania sprawozdania rachunkowego.

\section{DOPUSZCZALNOŚĆ STOSOWANIA PRZEZ SĄDY POSTĘPOWANIA PRZYMUSZAJĄCEGO DO ZŁOŻENIA SPRAWOZDANIA FINANSOWEGO}

W zakresie stosowania przepisów przez sądy rejestrowe pojawiła się nieprawidłowa praktyka stosowania przez sądy postępowania przymuszającego do złożenia sprawozdania finansowego. W wypadkach zawieszenia przez spółkę z o.o. prowadzenia działalności gospodarczej nie ma podstaw do zastosowania przepisu art. 24 ust. 1 k.r.s., gdyż postępowanie przymuszające może zostać wszczęte tylko w wypadku stwierdzenia, że wniosek o wpis do Rejestru lub dokumenty, których złożenie jest obowiązkowe, nie zostały złożone pomimo upływu terminu. W ta- 
kich sytuacjach sąd rejestrowy wzywa obowiązanych do ich złożenia, wyznaczając dodatkowy siedmiodniowy termin, pod rygorem zastosowania grzywny przewidzianej w przepisach Kodeksu postępowania cywilnego ${ }^{6}$ o egzekucji świadczeń niepieniężnych (postępowanie przymuszające).

Odmienne stanowisko zostało wyrażone w piśmie Ministra nr 15346 z dnia 11 października 2017 roku VIII/15346/2017 w sprawie składania przez przedsiębiorców, którzy zawiesili wykonywanie działalności gospodarczej, sprawozdań finansowych do Krajowego Rejestru Sądowego ${ }^{7}$. Stwierdzone zostało w nim bowiem, że sądy rejestrowe nie mają wystarczającej wiedzy do dokonania ustalenia,

czy każdy fakt permanentnego zawieszenia działalności gospodarczej w danym roku obrotowym jest warunkiem wystarczającym do niezłożenia dokumentów wymienionych w art. 69 ustawy o rachunkowości za ten rok i nie mogą dokonać merytorycznej oceny faktu niezłożenia takich dokumentów. Dlatego, z uwagi na nałożone przez ustawodawcę obowiązki kontrolne i nadzorcze wobec podmiotów rejestrowych, sądy rejestrowe wzywają przedsiębiorców, którzy zawiesili działalność gospodarczą, do złożenia w wyznaczonym terminie dokumentów finansowych, wymienionych w art. 69 ustawy o rachunkowości, albo złożenia oświadczenia o braku obowiązku sporządzenia i złożenia rocznego sprawozdania finansowego ${ }^{8}$.

Przedmiotowe pismo stanowiło próbę wyjaśnienia nieprawidłowego stosowania przez sądy rejestrowe trybu przymuszającego do składania sprawozdań finansowych przedsiębiorców, którzy nie mają takiego prawnego obowiązku. Wbrew powyższemu stanowisku zamiast wzywać do złożenia takiego sprawozdania pod rygorem nałożenia grzywny na podmioty reprezentujące spółki z o.o należałoby najpierw uzyskać informacje, a dopiero — w razie ich braku — po stosownym pouczeniu zastosować środki przymuszające. Stosowanej przez sądy praktyki związanej z wszczynaniem postępowania przymuszającego do złożenia sprawozdania finansowego nie można uznać za prawidłową czy też zgodną z obowiązującymi przepisami prawa. Postępowanie uruchamiane na podstawie przepisu art. 24 ust. 1 k.r.s. pełni bowiem innego rodzaju funkcję ochronną, gdyż ma służyć prawidłowej realizacji obowiązków finansowo-sprawozdawczych.

\section{SANKCJE ZA NIEDOPEŁNIENIE OBOWIĄZKÓW ZŁOŻENIA ROCZNEGO SPRAWOZDANIA FINANSOWEGO PRZEZ SPÓŁKI Z O.O.}

Sankcje za niedopełnienie obowiązków związanych ze składaniem rocznego sprawozdania finansowego w k.r.s. zostały określone w art. 79 pkt $4 \mathrm{w}$ ustawie

${ }^{6}$ Ustawa z dnia 17 listopada 1964 roku Kodeks postępowania cywilnego (tekst jedn. Dz.U. z 2019 r. poz. 1460), dalej: k.p.c.

${ }^{7}$ Legalis pisma urzędowe do art. 12 ust. 3b ustawy o rachunkowości, https://sip.legalis.pl/ document-full.seam?documentId=nfxhizlsfy4damzxgi2dmoi (dostęp: 14.05.2020).

8 Ibidem. 
o rachunkowości, w myśl którego, kto wbrew przepisom nie składa sprawozdania finansowego, sprawozdania z działalności, a także skonsolidowanego sprawozdania finansowego, sprawozdania $\mathrm{z}$ działalności grupy kapitałowej, sprawozdania z płatności na rzecz administracji publicznej, skonsolidowanego sprawozdania z płatności na rzecz administracji publicznej we właściwym rejestrze sądowym, podlega grzywnie albo karze ograniczenia wolności.

Jak dostrzega się w orzecznictwie ${ }^{9}$, przestępstwo określone w art. 79 ustawy o rachunkowości zaliczane jest do grupy przestępstw formalnych (bezskutkowych), co wynika z tego, że w opisie czynu zabronionego brakuje znamienia ustawowego w postaci skutku. W efekcie powoduje to, że organ orzekający zostaje zwolniony z obowiązku ustalenia, jak to jest w przypadku przestępstw materialnych, czy sprawca doprowadził do powstania skutku, jak również wykazania związku przyczynowo-skutkowego. Sąd Najwyższy zasadnie dostrzega, że

określenie przez ustawodawcę danego czynu jako przestępstwa, podporządkowane jest zasadniczemu celowi zwalczania czynów społecznie niebezpiecznych za pomocą kary. Wysoki stopień społecznej szkodliwości danej kategorii czynów jest, na etapie tworzenia prawa, podstawowym elementem zmuszającym racjonalnego ustawodawcę do wprowadzenia karalności danej kategorii zachowań, oraz istotnym czynnikiem wpływającym na rodzaj ustawowego zagrożenia,

co niewątpliwie ustawodawca uwzględnił, określając w art. 79 pkt 4 ustawy o rachunkowości kary wolnościowe (grzywna, ograniczenie wolności) ${ }^{10}$. Przy zaniechaniu dopełnienia obowiązków sprawozdawczych należy oceniać, czy obowiązek ten w efekcie został dopełniony, czy też zaniechanie wykonania tych obowiązków mogło spowodować wyrządzenie szkody, a także zamiar. Przedmiotowy przepis pośrednio ma zapewnić ochronę uczestników obrotu gospodarczego w uzyskaniu (na podstawie dokumentów, do których należy zaliczyć sprawozdania finansowe) danych o sytuacji majątkowej i gospodarczej spółki zgodnych z rzeczywistym stanem. Na podstawie informacji wynikających ze sprawozdań finansowych dokonywana jest ocena ewentualnych zagrożeń, jakie mogą powstać w związku z podejmowaniem czynności prawnych z podmiotem wpisanym do rejestru. Roczne sprawozdania finansowe stanowią zestawienie wyników działalności przedsiębiorców, których ujawnienie w rejestrze umożliwia ocenę kondycji finansowej przez odbiorców zewnętrznych. Sprawozdanie finansowe jest syntetycznym źródłem informacji o sytuacji finansowej podmiotu. Ponadto uznawane jest za użyteczny instrument służący do wymiany informacji między jednostką funkcjonującą w obrocie a zainteresowanymi nią użytkownikami ${ }^{11}$.

W wypadku przestępstwa określonego w art. 79 pkt 4 ustawy o rachunkowości zasadnicze znaczenie dla oceny stopnia społecznej szkodliwości czynu winna

9 Tak Sąd Najwyższy w wyroku z dnia 6 listopada 2014 roku w sprawie pod sygn. akt IV KK 200/14, Legalis nr 1160484 .

10 Ibidem.

11 M. Walczak, Rachunkowość polska na tle regulacji międzynarodowych, Łódź 2002, s. 11-12. 
mieć waga naruszonych przez sprawcę ustawowych obowiązków, a także czasokres ich niewypełniania. $Z$ tych względów ocena stopnia społecznej szkodliwości czynu powinna być oceną całościową, uwzględniającą okoliczności wymienione w art. $115 \S 2$ k.k. ${ }^{12}$

Sądy rejestrowe nie mogą zatem bezpodstawnie nakładać sankcji pieniężnych na podmioty, które skorzystały z uprawnienia przewidzianego w art. 12 ust. $3 \mathrm{~b}$ ustawy o rachunkowości, licząc na to, że podmiot wpisany do rejestru nie zaskarży takiego postanowienia. Takie działanie jest sprzeczne z zasadami praworządności i podważa zaufanie do organów sądowych.

W judykaturze wyrażono pogląd, że przepis art. 79 pkt 4 ustawy o rachunkowości, w którym penalizowane jest zachowanie polegające na nieskładaniu sprawozdania finansowego lub sprawozdania z działalności we właściwym rejestrze sądowym, odnosi się do niezrealizowania obowiązku określonego w art. 69 tej ustawy. Już z tego wynika, że analizowane przestępstwo nie może zostać popełnione, gdy jeszcze nie minął termin do zatwierdzenia sprawozdania. Dopiero uchybienie piętnastodniowemu terminowi po zatwierdzeniu wypełniałoby znamiona tego przestępstwa, nie mówiąc już o sytuacji, gdy nie minął nawet termin do jego sporząazenia. Oba wskazane terminy (do sporządzenia oraz zatwierdzenia sprawozdania), zgodnie z ustawą o rachunkowości, biegną od dnia bilansowego, który ustawa w art. 3 ust. 1 pkt 10 definiuje jako dzień, na który jednostka sporządza sprawozdanie bilansowe. Skoro przepis art. 79 ustawy o rachunkowości wymaga dla karalności określonego zachowania, by podjęte było wbrew ustawie, to wymogiem sądu powinno być wskazanie, jaki przepis ustawy nakładał dany obowiązek na oskarżonych (działania lub zaniechania), a kolejnym etapem powinno być szczegółowe określenie, na czym polegało zachowanie wbrew temu obowiązkowi, odnosząc to do realiów sprawy ${ }^{13}$. Tym bardziej nie ma żadnych podstaw do penalizowania zachowań, które zwalniają przedsiębiorcę z obowiązków sprawozdawczych. Przepis art. 12 ust. 3 b ustawy o rachunkowości przyznaje przedsiębiorcom prawo do tego, aby nie zamykać ksiąg rachunkowych za rok obrotowy, w którym działalność jednostki przez cały czas pozostawała zawieszona, jeżeli nie były dokonywane odpisy amortyzacyjne lub umorzeniowe lub nie występowały inne zdarzenia wywołujące skutki o charakterze majątkowym lub finansowym. Wskazane okoliczności musi mieć na uwadze sąd rejestrowy przy prowadzeniu postępowania wyjaśniającego w zakresie dopełnienia obowiązków sprawozdawczo-finansowych przez podmiot podlegający wpisowi do KRS-u. Nie można $\mathrm{w}$ związku z tym podzielić stanowiska, że sądy nie mają instrumentów prawnych, które pozwoliłby im na ustalenie tych okoliczności. Oczywiście, wprowadzenie zmian legislacyjnych służących nałożeniu obowiązku polegającego na

12 Por. wyroki Sądu Najwyższego: z dnia 18 maja 2006 roku, WA 9/06, R-OSNKW 2006, poz. 1762; z dnia 10 lutego 2009 roku, WA 1/09, R-OSNKW 2009, poz. 343.

13 Wyrok Sądu Najwyższego, Izba Karna z dnia 4 września 2013 roku, sygn. akt III KK 285/13, Legalis nr 733393 . 
składaniu wobec sądu rejestrowego oświadczenia o braku obowiązku sporządzenia i złożenia rocznego sprawozdania finansowego z powodu niezamknięcia ksiąg rachunkowych za dany rok obrotowy, ze względu na zawieszenie działalności w tym okresie, niedokonywanie w tym okresie odpisów amortyzacyjnych lub umorzeniowych, niewystępowanie w tym okresie innych zdarzeń wywołujących skutki o charakterze majątkowym lub finansowym należy ocenić pozytywnie.

Wdrożenie przez sąd rejestrowy procedury określonej w art. 24 ust. 1 ustawy k.r.s. będzie możliwe dopiero w sytuacji, kiedy przedsiębiorca, który zawiesił prowadzenie działalności gospodarczej, nie dopełni obowiązku wynikającego z przepisu art. 12 ust. 4 ustawy o rachunkowości. Stosownie do przedmiotowego przepisu ostateczne zamknięcie i otwarcie ksiąg rachunkowych jednostki kontynuującej działalność powinno nastąpić najpóźniej w ciągu 15 dni od dnia zatwierdzenia sprawozdania finansowego za rok obrotowy. Zamknięcie ksiąg rachunkowych jednostki powinno nastąpić w ciągu 3 miesięcy od dnia bilansowego, z zastrzeżeniem regulacji przewidzianej w art. 53 ust. 1 ustawy o rachunkowości. Przepis ten stanowi, że roczne sprawozdanie finansowe podlega zatwierdzeniu przez organ zatwierdzający, nie później niż 6 miesięcy od dnia bilansowego. W związku z tym ostateczne zamknięcie ksiąg rachunkowych powinno być dokonane najpóźniej 15 lipca następnego roku kalendarzowego, jeśli rokiem bilansowym jest rok kalendarzowy. Po tym dniu jednostki nie mają już możliwości wprowadzania żadnych zapisów do ksiąg rachunkowych dotyczących roku kalendarzowego, którego sprawozdanie dotyczy. Dopiero wówczas sąd rejestrowy może wszcząć postępowanie przymuszające, wcześniejsze zaś wszczęcie postępowania powinno skutkować umorzeniem tego postępowania jako niedopuszczalnego (por. art. 355 k.p.c.).

\section{ZMIANY UJEDNOLICAJĄCE REGULACJE ZWIĄZANE Z ZAWIESZENIEM PROWADZENIA DZIAŁALNOŚCI GOSPODARCZEJ}

W piśmie nr 15346 z dnia 11 października 2017 roku VIII/15346/2017 zaproponowano wprowadzenie zmiany polegającej na dodaniu w ustawie o rachunkowości przepisu, że kierownik jednostki będącej spółką jawną osób fizycznych lub spółką partnerską, której przychody netto ze sprzedaży towarów, produktów i operacji finansowych za poprzedni rok obrotowy wyniosły mniej niż równowartość w walucie polskiej 2000000 EURO i która nie stosuje zasad rachunkowości określonych ustawą na podstawie art. 2 ust. 2, składać będzie w sądzie rejestrowym prowadzącym Krajowy Rejestr Sądowy w terminie 6 miesięcy od dnia kończącego rok obrotowy oświadczenie o braku obowiązku sporządzenia i złożenia rocznego sprawozdania finansowego. Regulacja ta została wprowadzona przez dodanie na mocy art. 10 pkt 6 ustawy z dnia 26 stycznia 2018 roku o zmianie usta- 
wy o Krajowym Rejestrze Sądowym oraz niektórych innych ${ }^{14}$ przepisu art. 70a do ustawy o rachunkowości. Dzięki takiemu unormowaniu sądy rejestrowe uzyskają wystarczającą wiedzę o przyczynach niezłożenia rocznych sprawozdań finansowych przez przedsiębiorców, ale tylko wymienionych w powyższym przepisie, i nie będą miały podstaw do wszczynania wobec nich postępowań przymuszających do złożenia zaległych sprawozdań. Wejście w życie zmian do ustawy k.r.s. oraz ustawy Prawo przedsiębiorców ${ }^{15}$ miało wyeliminować dotychczasową nieprawidłową praktykę sądów rejestrowych. Niestety, wprowadzenie tej ograniczonej regulacji nadal nie rozwiązuje problemu odnoszącego się do spółek z o.o. i nieprawidłowej praktyki związanej z prowadzeniem przez sądy rejestrowe postępowań przymuszających.

Pozytywnie zatem należy ocenić wprowadzenie nowego przepisu art. 9a w brzmieniu:

1. Dla każdego podmiotu obowiązanego do składania dokumentów finansowych do Rejestru prowadzi się w systemie teleinformatycznym repozytorium dokumentów finansowych. 2. Do repozytorium dokumentów finansowych są składane dokumenty, o których mowa w art. 69 ustawy z dnia 29 września 1994 roku o rachunkowości (Dz.U. z 2018 r. poz. 395 i 398). 3. Każdy ma prawo przeglądania repozytorium dokumentów finansowych. 4. Centralna Informacja bezpłatnie udostępnia dokumenty z repozytorium dokumentów finansowych za pośrednictwem ogólnodostępnych sieci teleinformatycznych.

W sytuacji, kiedy tego rodzaju dokumenty nie zostaną złożone przez podmiot podlegający wpisowi do rejestru, powinno to stanowić dla sądu rejestrowego informację do podjęcia działań związanych z ustaleniem, czy podmiot złożył wniosek o wpisanie faktu zawieszenia prowadzonej działalności gospodarczej i czy ta okoliczność została ujawniona w rejestrze. Dopiero gdy nie zostały przez podmiot wpisane do rejestru podjęte działania związane ze zgłoszeniem faktu czasowego zaprzestania prowadzenia działalności gospodarczej, powinno zostać wdrożone postępowanie przymuszające do dopełnienia obowiązków sprawozdawczo-finansowych określonych $\mathrm{w}$ ustawie o rachunkowości. Natomiast $\mathrm{w}$ razie ustalenia przez sąd rejestrowy, że obowiązek zgłoszenia faktu zawieszenia czynności związanych z prowadzeniem działalności gospodarczej przez spółkę z o.o. został dopełniony, po podjęciu przez spółkę działalności gospodarczej sąd rejestrowy może wdrażać czynności określone w art. 24 ust. 1 ustawy o k.r.s. po upływie okresu do złożenia sprawozdania w przedmiocie zamknięcia ksiąg rachunkowych za dany rok kalendarzowy, w którym zawieszona była działalność gospodarcza.

14 Wprowadzone na mocy ustawy z dnia 26 stycznia 2018 roku o zmianie ustawy o Krajowym Rejestrze Sądowym oraz niektórych innych ustaw (Dz.U. z 2018 r. poz. 398), dalej: zm. k.r.s.

15 Ustawa z dnia 6 marca 2018 roku Prawo przedsiębiorców (tekst jedn. Dz.U. z 2019 r. poz. 1292). 


\section{ZMIANY PRZEPISÓW DOTYCZĄCE ZAWIESZENIA PROWADZENIA DZIAŁALNOŚCI GOSPODARCZEJ W ZWIĄZKU Z WEJŚCIEM W ŻYCIE USTAWY PRAWO PRZEDSIĘBIORCÓW}

Zagadnienie związane z zawieszeniem prowadzonej działalności gospodarczej, następnie jej podejmowaniem, budziło w praktyce stosowania prawa wątpliwości interpretacyjne. W związku z tym, mimo że częste zmiany ustaw nie są postrzegane pozytywnie, w niektórych przypadkach zmiany legislacyjne obowiązujących regulacji prawnych są konieczne. Do oczekiwanych i korzystnych zmian należy zaliczyć zarówno zmiany wprowadzone do ustawy o k.r.s. ${ }^{16}$, które weszły w przeważającej części z dniem 1 marca 2018 roku $^{17}$, jak i zmiany związane z wejściem w życie ustawy z dnia 6 marca 2018 roku Prawo przedsiębiorców ${ }^{18}$.

Ustawa Prawo przedsiębiorców ma wdrażać dyrektywę 2006/123/WE Parlamentu Europejskiego i Rady z dnia 12 grudnia 2006 roku dotyczącą usług na rynku wewnętrznym ${ }^{19}$. Ponadto - według założeń ustawodawcy — ustawa Prawo przedsiębiorców ma spełniać funkcję aktu prawnego o charakterze podstawowym i wiodącym w dziedzinach spraw związanych z podejmowaniem, wykonywaniem oraz zakończeniem na terytorium RP działalności gospodarczej, a także zadaniami organów władzy publicznej w tym zakresie ${ }^{20}$. Ustawa powinna być w związku z tym traktowana priorytetowo (jako funkcjonalnie i aksjologicznie nadrzędna) w procesach wykładni poszczególnych przepisów prawa odnoszących się do przedsiębiorców (niezależnie od tego, z jakich źródeł prawa się wywodzą). Zgodnie z przepisem art. 1 ustawy Prawo przedsiębiorców ustawa reguluje podejmowanie, wykonywanie i zakończenie działalności gospodarczej na terytorium Rzeczypospolitej Polskiej, w tym prawa i obowiązki przedsiębiorców oraz zadania organów władzy publicznej w tym zakresie. Za działalność gospodarczą uważa się — w myśl przepisu art. 3 wymienionej ustawy — zorganizowaną działalność zarobkową wykonywaną we własnym imieniu i w sposób ciągły. Za przedsiębiorcę uważa się osobę fizyczną, osobę prawną lub jednostkę organizacyjną niebędącą osobą prawną, której odrębna ustawa przyznaje zdolność prawną, wykonującą działalność gospodarczą ${ }^{21}$ W myśl regulacji art. 17 ust. 1 ustawy Prawo przed-

16 Ustawa z dnia 20 sierpnia 1997 roku o Krajowym Rejestrze Sądowym (tekst jedn. Dz.U. z 2017 r. poz. 700).

17 Wprowadzone na mocy zm. k.r.s.

18 Ustawa z dnia 6 marca 2018 roku Prawo przedsiębiorców Dz.U. z 2018 r. poz. 646, dalej: pr. przed.

19 Dz.Urz. UE L 376 z dnia 27 grudnia 2006 roku, s. 36.

20 Por. uzasadnienie projektu ustawy Prawo Przedsiębiorców, http://orka.sejm.gov.pl/opinie8. nsf/nazwa/2055_u/\$file/2055_u.pdf (dostęp: 2.04.2018).

${ }^{21} \mathrm{~W}$ kwestii prowadzenia działalności gospodarczej przez wspólników spółki cywilnej por. J. Frąckowiak, Jednostka organizacyjna jako substrat osoby prawnej i ustawowej, [w:] Rozprawy prawnicze: księga pamiątkowa Profesora Maksymiliana Pazdana, red. L. Ogiegła, W. Popiołek, M. Szpunar, 
siębiorców (Rozdział 2 Podejmowanie, wykonywanie i zakończenie działalności gospodarczej) działalność gospodarczą można podjąć w dniu złożenia wniosku o wpis do Centralnej Ewidencji i Informacji o Działalności Gospodarczej albo po dokonaniu wpisu do rejestru przedsiębiorców Krajowego Rejestru Sądowego, chyba że przepisy szczególne stanowią inaczej. Zgodnie z regulacją zawartą w przepisie art. 23 ust. 2 pr. przed. Przedsiębiorca wpisany do rejestru przedsiębiorców Krajowego Rejestru Sądowego może zawiesić wykonywanie działalności gospodarczej na okres od 30 dni do 24 miesięcy. Jeżeli okres zawieszenia wykonywania działalności gospodarczej obejmuje wyłącznie pełny miesiąc luty danego roku kalendarzowego, za minimalny okres zawieszenia wykonywania działalności gospodarczej przyjmuje się liczbę dni miesiąca lutego przypadającą w danym roku kalendarzowym (art. 23 ust. 3 pr. przed.).

Na mocy art. 24. ust. 1 pr. przed. zawieszenie wykonywania działalności gospodarczej oraz jej wznowienie następują na wniosek przedsiębiorcy, chyba że przepis odrębny stanowi inaczej. W wypadku przedsiębiorcy wpisanego do rejestru przedsiębiorców Krajowego Rejestru Sądowego okres zawieszenia wykonywania działalności gospodarczej rozpoczyna się od dnia wskazanego we wniosku o wpis informacji o zawieszeniu wykonywania działalności gospodarczej, nie wcześniej niż w dniu złożenia wniosku, i trwa do dnia wskazanego we wniosku o wpis informacji o wznowieniu wykonywania działalności gospodarczej, który nie może być wcześniejszy niż dzień złożenia wniosku (art. 24 ust. 3 pr. przed.). Wpis informacji o zawieszeniu wykonywania działalności gospodarczej oraz o wznowieniu wykonywania działalności gospodarczej, w przypadku przedsiębiorców podlegających obowiązkowi wpisu do rejestru przedsiębiorców Krajowego Rejestru Sądowego, następuje na podstawie przepisów o Krajowym Rejestrze Sądowym (art. 24 ust. 5 pr. przed.). Z tym zastrzeżeniem, że w wypadku przedsiębiorcy wpisanego do rejestru przedsiębiorców Krajowego Rejestru Sądowego okres zawieszenia wykonywania działalności gospodarczej trwa nie dłużej niż do dnia poprzedzającego dzień automatycznego wpisu informacji o wznowieniu wykonywania działalności gospodarczej na zasadach określonych w ustawie z dnia 20 sierpnia 1997 roku o Krajowym Rejestrze Sądowym. W wypadku zobowiązań o charakterze publicznoprawnym zawieszenie wykonywania działalności gospodarczej wywiera skutki prawne od dnia, w którym rozpoczyna się zawieszenie wykonywania działalności gospodarczej, do dnia poprzedzającego dzień wznowienia wykonywania działalności gospodarczej (art. 24 ust. 7 pr. przed.).

W okresie zawieszenia wykonywania działalności gospodarczej przedsiębiorca nie może wykonywać działalności gospodarczej i osiągać bieżących przychodów z pozarolniczej działalności gospodarczej (art. 25 ust. 1 pr. przed.). Przy czym w okresie zawieszenia wykonywania działalności gospodarczej przedsiębiorca:

Kraków 2005, s. 899-913; idem, Konstrukcja prawna spótki cywilnej, [w:] Ars et usus: księga pamiątkowa ku czci Sędziego Stanisława Rudnickiego, red. T. Ereciński, S. Gudowski, Warszawa 2005, s. 107-123. 
1) może wykonywać wszelkie czynności niezbędne do zachowania lub zabezpieczenia źródła przychodów, w tym rozwiązywania zawartych wcześniej umów; 2) może przyjmować należności i jest obowiązany regulować zobowiązania powstałe przed datą zawieszenia wykonywania działalności gospodarczej; 3) może zbywać własne środki trwałe i wyposażenie; 4) ma prawo albo obowiązek uczestniczyć w postępowaniach sądowych, postępowaniach podatkowych i administracyjnych związanych z działalnością gospodarczą wykonywaną przed datą zawieszenia wykonywania działalności gospodarczej; 5) wykonuje wszelkie obowiązki nakazane przepisami prawa; 6) może osiągać przychody finansowe, także z działalności prowadzonej przed datą zawieszenia wykonywania działalności gospodarczej; 7) może zostać poddany kontroli na zasadach przewidzianych dla przedsiębiorców wykonujących działalność gospodarczą; 8) może powołać albo odwołać zarządcę sukcesyjnego, o którym mowa w ustawie z dnia 5 lipca 2018 roku o zarządzie sukcesyjnym przedsiębiorstwem osoby fizycznej i innych ułatwieniach związanych z sukcesją przedsiębiorstw (art. 25 ust. 2 pr. przed.).

Powyższa regulacja niewątpliwie ujednolica przepisy związane z zawieszeniem i podejmowaniem prowadzenia działalności gospodarczej w jednym akcie prawnym, wprowadzając jednocześnie reguły wykładni, jaka powinna być stosowana przez organy publiczne w zakresie stosowania przepisów prawa dotyczących przedsiębiorców.

\title{
SUSPENSION AND ESTABLISHMENT OF A BUSINESS BY A LIMITED LIABILITY COMPANY
}

\author{
Summary
}

The study describes the previous incorrect legal regulations and their effects in the scope of suspension of business activity by a limited liability company. In addition, the issue of the admissibility of courts applying coercive proceedings to submit financial statements was presented. It is indicated what types of sanctions may be applied for failure to submit annual financial statements by limited liability companies. Finally, changes introduced to harmonise the regulations related to the suspension of business activity were discussed.

Keywords: economic activity, limited liability company, suspension and commencing economic activity

\section{BIBLIOGRAFIA}

Frąckowiak J., Jednostka organizacyjna jako substrat osoby prawnej i ustawowej, [w:] Rozprawy prawnicze: ksiegga pamiatkowa Profesora Maksymiliana Pazdana, red. L. Ogiegła, W. Popiołek, M. Szpunar, Kraków 2005. 
Frąckowiak J., Konstrukcja prawna spótki cywilnej, [w:] Ars et usus: księga pamiatkowa ku czci Sędziego Stanisława Rudnickiego, red. T. Ereciński, S. Gudowski, Warszawa 2005.

Walczak M., Rachunkowość polska na tle regulacji międzynarodowych, Łódź 2002. 